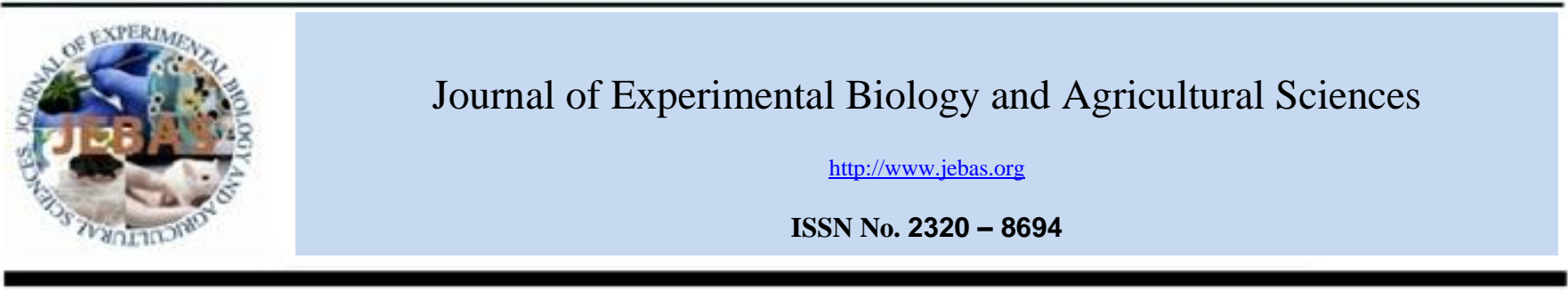

CANINE PARVOVIRUS- AN INSIGHT INTO DIAGNOSTIC ASPECT

\title{
Minakshi $\mathrm{P}^{1, *}$, Basanti Brar ${ }^{1}$, Sunderisen $\mathrm{K}^{1}$, Jiju V Thomas ${ }^{2}$, Savi $\mathrm{J}^{1}$, $\mathrm{Ikbal}^{1}$, Koushlesh Ranjan ${ }^{3}$, Upendera Lambe ${ }^{1}$, Madhusudan Guray ${ }^{1}$, Nitish Bansal ${ }^{1}$, Pawan Kumar ${ }^{1}$, Vinay G Joshi ${ }^{1}$, Rahul Khatri $^{4}$, Hari Mohan ${ }^{4}$, C S Pundir ${ }^{5}$, Sandip Kumar Khurana ${ }^{6}$ and Gaya Prasad ${ }^{3}$
}

${ }^{1}$ Department of Animal Biotechnology LUVAS, Hisar, Haryana- 125004, India

${ }^{2}$ University of Minnesota, USA

${ }^{3}$ SVPUAT, Meerut, U.P. India

${ }^{4}$ Centre for Medical Biotechnology, Maharshi Dayanand University, Rohtak, Haryana-124001, India

${ }^{5}$ Department of Biochemistry, MDU, Rohtak, Haryana-124001, India

${ }^{6}$ NRCE, Hisar, Haryana, India

Received - April 18, 2016; Revision - April 25, 2016; Accepted - May 21, 2016

Available Online - May 25, 2016

DOI: http://dx.doi.org/10.18006/2016.4(3S).279.290

\section{KEYWORDS \\ CPV \\ Antigenic variation \\ Diagnosis \\ PCR \\ VP2 gene}

\begin{abstract}
Canine parvovirus (CPV) leads to an acute disease, characterized by hemorrhagic gastroenteritis, vomiting and myocarditis in dogs. The disease can affect dogs of any age but is fatal in pups. CPV has undergone genetic variations that have led to emergence of various CPV-2 antigenic variants such as $2 \mathrm{a}$, $2 \mathrm{~b}$ and $2 \mathrm{c}$ with replacement of the original CPV-2 circulating in the dog population. CPV genome is made up of $5.2 \mathrm{~Kb}$ nucleotides. Viral protein VP2 plays a very important role in determining antigenicity and host range specificity of CPV. The antigenicity as well as host range of CPV is determined by virus specific VP2 protein. That's why the mutations that affect the VP2 gene are the main source of different antigenic variants. It spreads rapidly in the wild population of canines as well as domestic animals, infected feces serve as a main source of infection because the virus is shed in large quantity in the feces particularly $4-7$ days post infection. The present review is focused on various
\end{abstract}

* Corresponding author

E-mail: minakshi.abt@gmail.com(Minakshi P)

Peer review under responsibility of Journal of Experimental Biology and Agricultural Sciences.

Production and Hosting by Horizon Publisher India [HPI] (http://www.horizonpublisherindia.in/).

All rights reserved.
All the article published by Journal of Experimental Biology and Agricultural Sciences is licensed under a Creative Commons Attribution-NonCommercial 4.0 International License Based on a work at www.jebas.org.

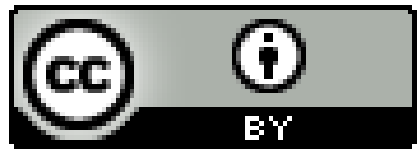


biotechnological approaches used for diagnosis of CPV along with some conventional techniques including gold standard virus isolation in animal cell culture, hemagglutination test, electron microscopy, enzyme linked immunosorbent assay (ELISA). The biotechnological approaches such as polymerase chain reaction (PCR), Real-time-PCR, Loop-mediated isothermal amplification (LAMP), Bead based multiplexing, Microarray chip and DNA probe etc. have also assured their application. These approaches provide rapid, sensitive, optimal detection and effective control of CPV infection.

\section{Introduction}

Canine Parvoviruses (CPVs) are small, non-enveloped viruses belonging to the Genus Parvovirus in the family Parvoviridae. Its genome is comprised of linear, negative-sense, single standard DNA of about $5.2 \mathrm{~kb}$ size, and encodes two structural (VP1 and VP2) and two non-structural (NS1 and NS2) proteins (Mochizuki et al., 1993). The first evidence of CPV infection in dogs dates back to 1970 s and was identified as canine parvovirus type 2 (CPV 2) (Burtonboy et al., 1979). This CPV2 isolate was likely to be a variant of Feline panleukopenia virus (FPV) because of detection of active circulation of intermediate viruses between FPV and CPV-2 in wild carnivores (Truyen, 2006). These two differed in at least six amino acids which are mostly located on VP2 protein (Truyen et al., 1995). Since then, CPV-2 has been identified globally and now, it is endemic in most populations of wild canines (Driciru et al., 2006, Ramsauer et al., 2007). Two new antigenic types of CPV-2 i.e. CPV-2a and CPV-2b differed at two amino acid positions, N426D and I555V (Truyen, 2006) and have became wide spread (Hoelzer et al., 2008).

The Asp-426 Glu substitution in capsid protein of CPV-2 generate a new variant known as CPV-2c which may infects several canine breeds (Buonavoglia et al., 2001, Decaro et al., 2006; Castro et al., 2007; Gombac et al., 2008). During acute phase of infection dogs may excrete virion particles up to 109/gram of faeces (Carmichael \& Binn, 1981). Moreover, CPV-2 virion particles are very stable in environment which facilitates its transmission through faecal-oral route.

Canine parvovirus (CPV) infection is a highly infectious viral disease of dogs of great concern for pet owners, veterinarians and scientists due to its high morbidity and mortality rates associated. Parvovirus infects dogs of all age groups, but puppies are more affected than adults. The initial clinical signs of CPV infection are nonspecific and include anorexia, depression, lethargy, and fever. Within 24 to 48 hours, most affected dog starts vomiting and hemorrhagic small-bowel diarrhea results severe dehydration. With severe dehydration, protein loss, concomitant infection, and inability to produce a rapid immune response, further weakening the dog. In last, all of these factors can lead to shock and death (Bargujar et al., 2011). The current knowledge of epidemiology, pathogenesis, clinical findings and diagnosis of canine parvoviral enteritis was briefly highlighted (Geetha, 2015; Shim et al., 2015). CPV in faecal samples has been detected by several methods based on virus isolation in cell culture, haemagglutination (HA), electron microscopy, enzyme linked immunosorbent assay (ELISA) and DNA hybridization.

Several molecular diagnostics assays such as polymerase chain reaction (PCR), multiplex PCR, Reverse Transcriptase PCR (RT-PCR), nucleic acid sequencing, Real Time-PCR, DNA probe etc have provided the unparalleled identification and discrimination ability for several viral pathogens (Minakshi et al., 2014; Kaur et al., 2015). Such diagnostic techniques should be transferred to end users for proper applications.

\section{Conventional Methods}

\subsection{Viral Isolation}

Various cell cultures viz. Crandell Feline Kidney cell line (CRFK), Madin Darby canine Kidney cell line (MDCK), Walter Reed Canine Cell line (WRCC) have been used for the isolation of $\mathrm{CPV}$ from the clinical samples for diagnosis of canine parvovirus. CPV is primarily isolated in laboratory in canine lung and kidney cell line. It produces characteristics cytopathic effects (CPE) such as presence of intranuclear inclusion bodies in host cell, detachment and rounding of cells (Figure 1A, B). However, cell culture is not used as a routine diagnostic test because it is a time consuming process, require permissive cell lines, low sensitivity and requires skilled personnel. Moreover, the sensitivity of different cell lines for CPV multiplication may also vary. CPV-2 can be isolated from cell culture only after few days of inoculation (Desario et al., 2005).

\subsection{Electron Microscopy}

Electron microscope can also be used for morphological identification of CPV2. Under electron microscope CPV may be seen as either single virion particle or in group of few viruses (Amo et al., 1999). On 3rd to 9th day of infection viruses are excreted in large quantity in faeces, thus, this period is best for electron microscopic study of CPV-2 from fecal samples. However, electron microscopy needs large quantity of virus to confirm a sample as positive, because electron microscopy is less sensitive in comparison to other molecular tests (Esfandiari \& Klingeborn, 2000). Electron microscopy was successfully used for diagnosis of canine parvoviral enteritis in fecal sample (Klingeborn \& MorenoLópez, 1980). 


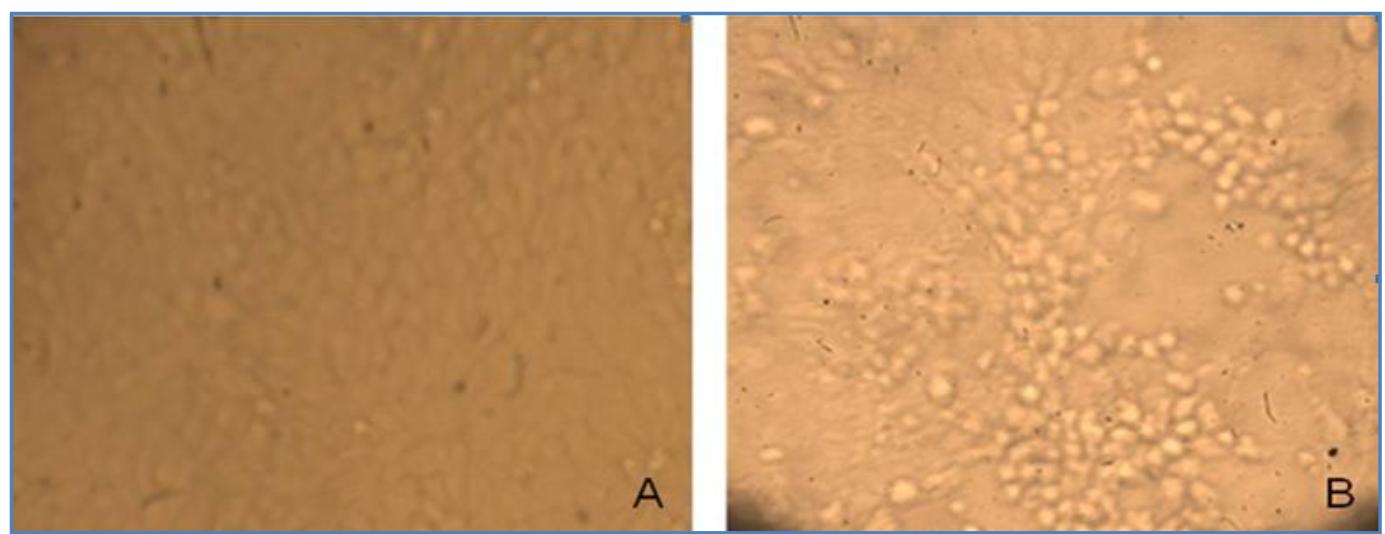

Figure 1. A) Micro-photograph of CRFK Cell line after 48 hours of growth; B) Micro-photograph of CRFK Cell line showing CPE after 48 hours of infection.

\subsection{Haemagglutination (HA) Assay}

Haemagglutination is specific, rapid and inexpensive test for CPV diagnosis. Haemagglutination is one of the important properties of Canine parvovirus. CPV has binding ability for sialic acid receptors on cell surface and agglutinates the RBCs of several animal species such as rhesus monkey, African green monkey, and Porcine etc (Burtonboy et al., 1979; Carmichael et al., 1980; Parrish et al., 1988). Seroprevalance studies among CPV2a infected dogs was reported using haemagglutination inhibition assay in North Korea (Klingeborn \& Moreno-López, 1980; Deepa \& Saseendranath, 2012). Two diagnostic assays was compared for their sensitivity and specificity and found that diagnostic accuracy of the ELISA was significantly greater than the IFA (Luren et al., 2012). However, the serology based diagnostic assays must be used with caution because in most of the cases dogs may show positive serological tests for CPV-2. This may happen due to administration of CPV-2 vaccine in large dog population and also the endemic nature of virus in several areas which may lead to inapparent infection and generation of antibody titer. Monoclonal antibodies based antigenic typing of canine parvovirus (CPV2a and CPV2b) was reported (Shankar et al., 2014).

\subsection{Latex agglutination test}

In latex agglutination tests the latex micro beads are coated with microbes specific either antigen or antibody, which can be used for detection of either microbe specific antibody or antigen in agglutination reaction. Positive result is detected by visualization of agglutination reaction which is characterized by clumping of micro beads with microbial antigen or antibody. Bodeus (1988) detected the CPV specific antibodies from field sample through latex agglutination test. Moreover, a new technology called SAT-SIT technology can be used for rapid detection of several other emerging hemagglutinating viruses from animals and humans (Marulappa \& Kapil, 2009).
2.5 Counter immuno electrophoresis

A laboratory technique used to evaluate the binding of an antibody to its antigen. Counter immuno electrophoresis uses electric field in diffusion medium which is made up of polyacrylamide gel or agarose. The electric field facilitates the rapid migration of antibody and antigen towards each other so that line of precipitation will form at earlier than simple diffusion reaction. The line of precipitation indicates the binding of antibody with antigen hence positive result. Mixed infections for coronavirus antigen with canine parvovirus was detected by counter immuno electrophoresis in fecal samples (Ganesan et al., 1990). The prevalence of canine parvovirus infection was reported in clinically suspected dogs AGID and CIEP (Deepa \& Saseendranath, 2012).

\subsection{Fluorescent antibody test}

In fluorescent antibody test an antibody tagged with fluorescent dye is used for detection of specific antigen. Based on tagging of fluorescent dye either on primary antibody or secondary antibody, the test may be either direct or indirect fluorescent tests. In direct fluorescent antibody test, the antibody binds directly with specific antigen and gives specific fluorescence signals for antigen detection. Fresh frozen tissues and formalin fixed are used to detect CPV using immunofluroscence (IFA) and immunoperoxidase (PAP).

PAP gives more permanent, high resolution and clear intracellular localization of antigen than IFA (MaCartney et al., 1986). A semiquantitative ELISA and an immunofluorescence assay (IFA) were conducted for senstivity and specificity of canine parvovirus (Gray et al., 2012). An indirect fluoroimmunoassay using magnetic protein micro bead was validated for identification of antibodies against canine viruses such as CPV, CDV and rabies (Wang et al., 2011). 
Table 1 PCR assays developed for detection of canine parvovirus.

\begin{tabular}{|c|c|c|c|}
\hline S. No & Technique & Gene/ target & Reference \\
\hline 1. & $\begin{array}{l}\text { VP2 gene amplified by PCR and cloned in pTargeT mammalian } \\
\text { expression vector. VP2 gene was selected on the basis of restriction } \\
\text { enzyme analysis and further confirmed by sequencing. The present } \\
\text { work has shown that the recombinant plasmid could be used as DNA } \\
\text { vaccine against canine parvovirus infection. }\end{array}$ & VP2 gene & Gupta et al., 2005 \\
\hline 2. & $\begin{array}{l}\text { Epidemiological study of canine parvovirus infection and analyzed by } \\
\text { PCR assay. }\end{array}$ & $\begin{array}{l}\text { sequences specific for } \\
\text { CPV variant strains }\end{array}$ & Behera et al., 2015 \\
\hline 3. & CPV-2a strains detected by PCR-RFLP & VP2 gene & $\begin{array}{l}\text { Demeter et al., } \\
2010\end{array}$ \\
\hline 4. & $\begin{array}{l}\text { PCR was carried for VP2 capsid gene to detect all types of CPV, } \\
\text { (CPV-2a/2b/2c) including the new CPV-2c }\end{array}$ & VP2 gene & Silva et al., 2013 \\
\hline 5. & Genomic typing of canine parvovirus using PCR & $\begin{array}{l}\text { sequences specific for } \\
\text { CPV variant strains }\end{array}$ & Costa et al., 2005 \\
\hline 6. & $\mathrm{CPV}$ and its variants typing using PCR & $\begin{array}{l}\text { sequences specific for } \\
\text { CPV variant strains }\end{array}$ & Shankar et al., 2014 \\
\hline 7. & Characterization of canine parvovirus by PCR & $\begin{array}{l}\text { sequences specific for } \\
\text { CPV variant strains }\end{array}$ & Pereira et al., 2000 \\
\hline 9. & Analysis of VP2 gene sequences of canine parvovirus isolates & $\begin{array}{l}\text { VP2 } \\
\text { gene }\end{array}$ & $\begin{array}{l}\text { Chinchkar et al., } \\
2006\end{array}$ \\
\hline 10. & $\begin{array}{l}\text { molecular characterization and phylogenetic analysis of canine } \\
\text { parvovirus by PCR }\end{array}$ & $\begin{array}{l}\text { sequences specific for } \\
\text { CPV variant strains }\end{array}$ & $\begin{array}{l}\text { Mohan Raj et al., } \\
2010\end{array}$ \\
\hline 11. & $\begin{array}{l}\text { Typing of canine parvovirus using mini-sequencing based SNP } \\
\text { analysis }\end{array}$ & $\begin{array}{l}\text { sequences specific for } \\
\text { CPV variant strains }\end{array}$ & Naidu et al., 2012 \\
\hline 12. & Detection of canine parvovirus by PCR assay & $\begin{array}{l}\text { VP1 and VP2 } \\
\text { gene }\end{array}$ & Singh et. al., 2013 \\
\hline
\end{tabular}

\subsection{Enzyme Linked Immunosorbent Assay}

The IgM antibodies indicate the recent infection of pathogen. These antibodies were derived in a number of laboratories; all appear to bind to the amino-terminal region of the major core protein. The sensitivity of ELISA tests is found to be much higher that other serological assays such as immunodiffusion test, HA or HI test (Banja et al., 2002). The sensitivity and specificity of sandwich ELISA for detection of CPV in dog fecal sample was found much higher than HA test (Rimmelzwaan et al., 1991; Drane et al., 1994). A point-ofcare ELISA test kit yielded accurate results and highly sensitive and specific for detection of both CPV as well as CDV infection under field conditions. The Point-of-care ELISA system was used for identification of antibodies against CPV and CDV. This assay can be useful in animal vaccination programme and their care and management for outbreak of such disease (Litster et al., 2012). CPV antigens can also be identified in fecal samples by Sandwich ELISA (Deka et al., 2015)

\section{Nucleic Acid Based Methods}

Various nucleic acid based detection technique has been developed for the confirmation of CPV in the clinical samples. These techniques are fast, sensitive and specific and are discussed below:

\subsection{Polymerase Chain Reaction (PCR)}

PCR is a modern diagnostic assay which utilizes the specific amplification of desirable DNA sequence using template specific primer and DNA polymerase enzyme. It can also be used for diagnosis of those pathogens which may not be grown in laboratory condition. PCR assay has been used for diagnosis of several animal and human viruses. It can also detect viruses at early stage of infection before eliciting immune response and onset of clinical symptoms. Thus PCR may help in formulating policies for control and prevention of disease at early (Sharma et al., 2012). It can detect CPV from a samples having very minute quantity of virus. This assay is also much rapid and specific that gel filtration test. The samples having fecal inhibitory substances can be passing through spin column to remove inhibitory substances (Uwatoko et al., 1995). Molecular typing of CPV was done by using PCR based assays and CPV-2a and CPV-2b types were detected (Gauri et al., 2012). The PCR is a rapid, sensitive and specific method for detecting canine parvovirus (Savi et al., 2010, Figure. 2A, B). There are different researcher were used the PCR techniques for the diagnosis and detection of canine parvovirus as Table 1. Now a says several modifications of PCR such as multiplex PCR, Real-time PCR, nested PCR etc are used for molecular detection of viruses. Moreover, PCR amplicons can be used for nucleic acid sequencing and phylogenetic study for confirmatory diagnosis and tracking evolutionary history of virus. 


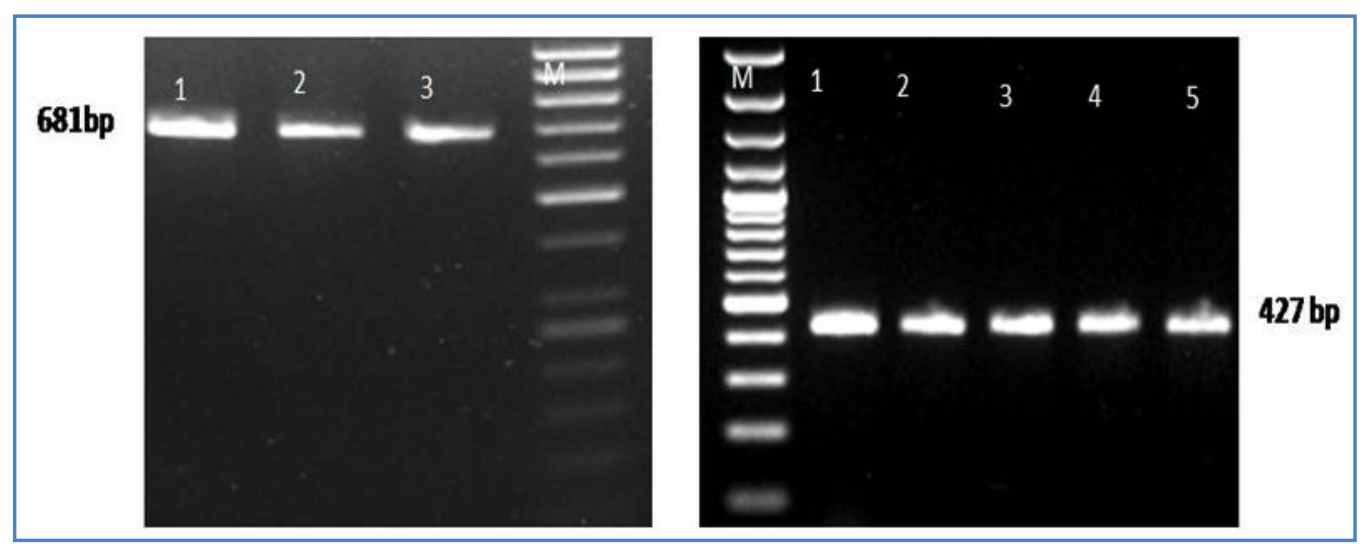

Figure 2 A) Genotyping of CPV isolate 2a; Lanes: M-100bp Marker, lane 3: control, lane 2: vaccine lane 1: field samples; B) genotyping of CPV isolate 2b, lanes: M-100bp Marker, lane 1: control, lane 2: vaccine lane 3 to 5: field samples

\subsection{Multiplex PCR}

Multiplex PCR utilizes the power of PCR using several primer sets of different amplicons size for different pathogens in a single reaction. Multiplex PCR enables the presence of nucleic acids from several pathogens to be checked for in one test, but care must be taken to avoid interference between primer pairs or templates. It is a time as well as cost effective methods because it can detect several pathogens simultaneously. Multiplex PCR assay can also be used for simultaneously identification of canine Leptospira sp and CPV (Ramadass \& Latha, 2005). The CPV-2a and CPV-2b strains were also differentiated using multiplex PCR assay (Parthiban et al., 2010).

\subsection{Real-Time PCR}

The real-time PCR is used for quantification of PCR product in reaction which can be used for estimation of viral load in sample. TaqMan assay based Real time PCR (RT-PCR) has been used for the detection of CPV-2 DNA in sample and an attractive tool for revealing single nucleotide polymorphisms in the capsid protein gene between CPV types $2 \mathrm{a}$ and $2 \mathrm{~b}$ and CPV types 2b and 2c (Decaro et al., 2006). The advantage of the real time PCR is that there is no need to analyse the PCR product by agarose gel electrophoresis. Everything will be graphically shown on the monitor of the computer. Another advantage is that amount of the DNA present in the sample can be quantitated. Recently, SYBR Green based real time PCR has been developed for quantitation of CPV-2 variants in faecal samples of dogs (Kumar et al., 2010). Canine parvovius infection was detected in feces of free-ranging wolves using real time PCR and the assay was $100 \%$ sensitive and specific with a minimum detection threshold level (David et al., 2012).

RT-PCR method was used for the amplification of rotavirus RNA, BTV as well as for CPV viruses using Taqman probe and SYBR Green chemistry (Decaro et al., 2005; Anamul et al., 2015; Feng et al., 2015). The SYBR Green-based real-time PCR assay was used for the amplification of CPV 2, FPV and PPV DNA, with a reproducible limit of detection of as few as 10 copies $/ \mu \mathrm{L}$ of target DNA per reaction and this study have been used successfully in veterinary diagnostic laboratory and have been helpful tools for the diagnosis and quantification of parvovirus infection in canines, felines and swine (Lin et al., 2014).

\subsection{Multiplex Real-Time PCR}

The term multiplex real-time PCR is used to describe the use of two to four fluorogenic oligoprobes for the discrimination of multiple amplicon. To date, there have been only a few truly multiplexed realtime PCR assays described in the literature. The use of non-fluorescent quenchers and the continuous development of better light sources in the machines are now in use and first applications for virus detection are becoming available. The vp2 gene based Multiplex Real-Time PCR was validated for simultaneously identification of CPV, FPV and PPV. Multiplex real time PCR have been used to detect and quantify CPV (Decaro et al., 2007; Wei et al., 2009; Zhao et al., 2013). Further, Kaur et al., 2016 reported that multiplex real time PCR assay could be used for rapid detection of CPV as well as typing of its three antigenic types.

\subsection{PCR-Restriction Fragment Length Polymorphism (PCR- RFLP)}

RFLP uses specific restriction enzymes for study of restriction pattern of viral nucleic acid. However, this is a time consuming technique. However, through PCR small quantity of viral nucleic acid can be amplified and used for RFLP analysis. The RFLP technique was successfully used for differentiation of CPV-2 antigenic variants (Savi et al., 2009; Zhang et al., 2010). 


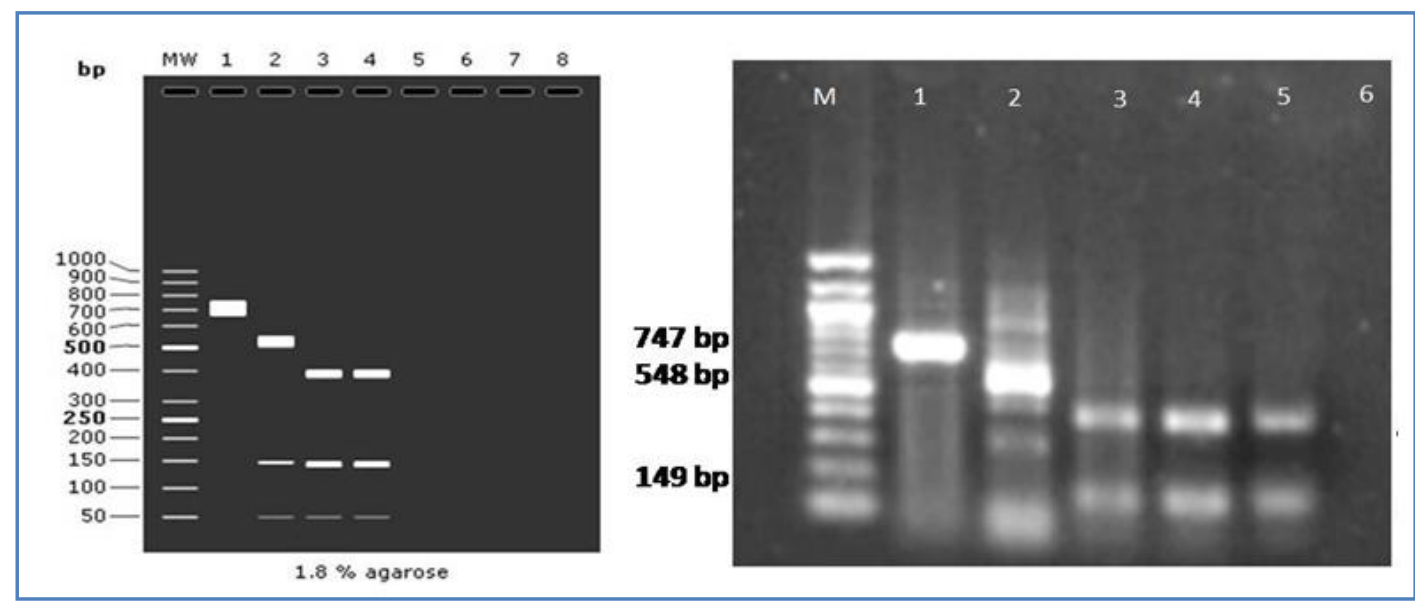

Figure $3 \mathrm{~A}$ ) Insilco RE of 747bp amplified product, M-100bp Marker, lane 1: undigested 747bp product, lane 2: vaccine digested to give 548, 149 and 50bp products: lane 3\& 4: field isolates digested to give $402 \mathrm{bp}, 148$ and $145 \mathrm{bp} 50$ bp products. B) Restriction enzyme digestion of $747 \mathrm{bp}$ PCR product Lane M: 100bp ladder (MBI Fermentas) 1: Uncleaved PCR product of Canine parvovirus field strains (747bp) 2: PCR product of vaccine strain digested by Rsa I to give $548,149 \& 50$ bp products 3-5: PCR product of samples digested by Rsa I to give 402,149,146; \& 50 bp . 6: Water control.

RFLP technique was also engaged in differentiation of CPV-2b and CPV-2c strains (Gauri et al., 2012). The partial VP2 gene specific PCR assay was standardized with corresponding consensus primers to amplify the desired length (747bp) of product. The PCR assay was carried out using the published partial VP2 gene specific primers (Sakulwira et al., 2001). Amplified 747 bp product was used for in silico restriction enzyme profiling. Reference sequences for vaccine and field strains were retrieved from the NCBI and loaded into the Insilco restriction enzyme profiling software (SNAP GENE SOFTWARE) \& the resultant profiles were observed and images were obtained (Figure 3A). In wet-lab restriction enzyme profiling restriction enzyme RsaI (New England Biolabs) was used for template digestion. The different Restriction enzyme gave different RE digested products from both vaccines as well as field strain. The resultant digested products were resolved in $4 \%$ agarose gel electrophoresis (Figure. 3 B).

\subsection{Peptide nucleic acid-based (PNA) array}

Peptide nucleic acid (PNA), are considered as a stable nucleic acid analogue. It contains pseudo-peptide skeleton in place of sugar phosphate backbone which is chemically and biologically highly stabile. PNAs hybridize to cRNAs or cDNAs more efficiently than DNA. It possibly happens due to electrically neutral nature of PNA backbone. Peptide nucleic acid-based (PNA) array was used to discriminate between the four CPV-2 antigenic types (CPV-2, $-2 \mathrm{a},-2 \mathrm{~b}$, and $-2 \mathrm{c}$ ) during ante-mortem diagnosis of dogs, using newly developed PNADNA hybridization assay. The PNA array has high sensitivity and specificity compared with a real time PCR using the TaqMan assay, a gold standard method (An et al., 2012).

\subsection{Nucleic acid hybridization assay}

The VP1 and VP2 protein specific digoxigenin labeled probe have been developed for detection of CPV. This probe may also be used for in situ hybridization and detection of CPV from immobilized tissue samples in formalin and paraffins (Nho et al., 1997). Further, Decaro et al. (2005) develop two minor groove binders (MGB) fluorophores (FAM and VIC) labeled probe for rapid quantification of CPV-2 variants in dog fecal samples. The MGB probe was able to detect SNPs in CPV $2 a / 2 b$ and $2 b / 2 c$. Both the MGB probe assays were found to be highly specific, sensitive and reproducible as compared to other methods used to detect the virus.

\subsection{Loop-mediated isothermal amplification (LAMP) assay}

LAMP assay is considered as alternative to conventional nested PCR. LAMP assay can be used for detection of DNA of several viruses of animal and human origin. In comparison to nested-PCR, LAMP assay are proved to be more rapid, sensitive and fairly reproducible method. It did not amplify other canine pathogens (Parthiban et al., 2012). Detection of canine parvovirus in fecal samples was reported using loopmediated isothermal amplification (Cho et al., 2006). A detection system based on the application of LAMP in conjunction with ELISA and LFD for convenient visual detection of CPV with high sensitivity and specificity was developed (Sun et al., 2014). Mukhopadhyay et al. (2012) standardized a highly sensitive and specific LAMP assay for detection of CPV DNA from fecal samples. The assay showed result within one hour. Recently, VP2 gene based LAMP PCR assay has been developed (Figure 4). The assay is 30 times more sensitive than conventional PCR (unpublished data). 


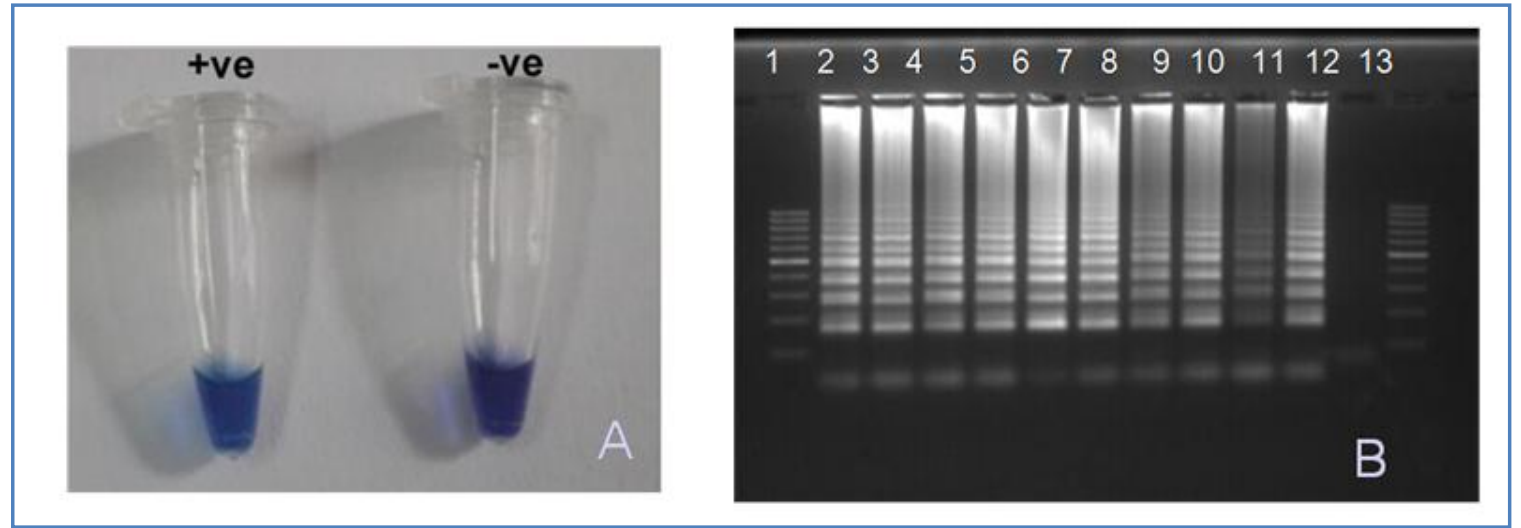

Figure 4 A) Hydroxy Napthol Blue based visual LAMP assay for colorimetric discrimination of positive and negative samples for parvovirus B) PCR amplification of LAMP assay; 2-10 Tenfold serial dilutions of template $10^{9}$ to $10^{1}$, 11: Clinical CPV sample 12: Negative control, 1\&13: molecular Marker.

\subsection{Whole genome amplification and sequencing}

Complete coding sequence of canine parvovirus genome could be amplified by sequence specific primer. Pick-primer software is available in the NCBI BLAST to design these primers. To attain the maximal coding sequences overlapping of primers with their forward and reverse sequence is preferred. Optimization of PCR reaction mixture and thermocyclic conditions is very important for amplification. The annealing temperature may vary with each primer and it should be standardized for the amplification. The products resolved in 1\% agarose gel to observe the amplification (Figure $5)$.

\subsection{Phylogenetic analysis}

The nucleotide sequences of pathogens are used for phylogenetic study which shows its evolutionary relationship and closeness with other strains of same or different virus species.
The phylogenetic studies of CPV vaccine strains in India have been done (Nandi et al., 2010). Phylogenetic studies also revealed the fact that Indian CPV variants are closely related among themselves. The CPV variants also showed little divergence from their ancestor MEVs (Singh et al., 2014).

The sequences were aligned against the other published CPV VP1/VP2 gene sequences using software from DNASTAR. The amino acid sequence, phylogenetic maps and percentage homology were deduced and analyzed from the sequences using the same software. The phylogenetic tree revealed that CPV2 and both CPV vaccine strains were in separate monophyletic group. The VP gene sequences of the Haryana isolate and gene sequences of various global isolates were used for phylogenetic analysis. The phylogenetic tree developed on the basis of VP gene indicated that the Hisar isolate is clustering with the Chinese isolate (Acc. No. JQ686671.1) as a separate group than rest of the Chinese isolates, Russian and USA isolates which indicates that the Hisar field isolate and the Chinese isolate originated from a common ancestor CPV (Figure 6).

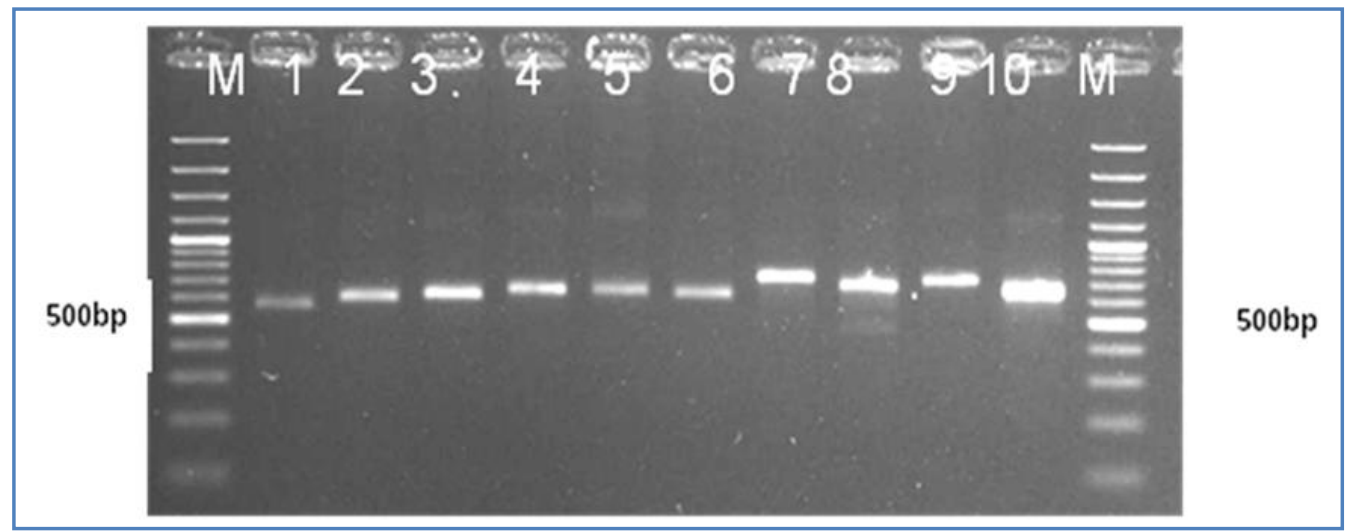

Figure 5 whole genome amplification of CPV field isolate (sample no; 915/H) by primer walk technique. M-100bp Marker, lane 1 to 9: Amplified primer products by primers 2 to 10 , lane 10: primer $12^{\text {th }}$ amplified product. 


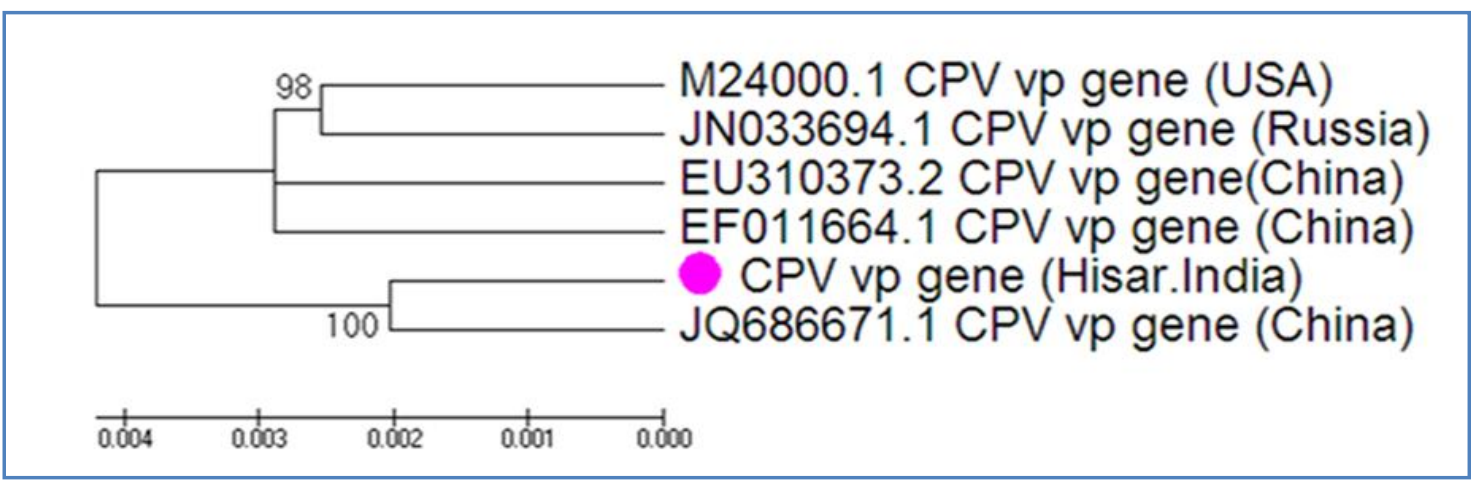

Figure 6: Phylogenetic tree based on VP gene obtained from Hisar isolate to that of global isolate.

\subsection{Biosensor}

Biosensor is an analytical device which converts biological responses to electrical signals. It is used for rapid diagnostic method which helps to detect disease in low sample with high selectivity and specificity in seconds. Disadvantage is that heat sterilization is not possible. A biosensor is also developed to detect CPV infection using Quartz Crystal Microbalance (QCM) biosensor and prolinker B to rapidly diagnose CPV infection. ProLinker ${ }^{\mathrm{TM}} \mathrm{B}$ enables antibodies to be attached to a gold-coated quartz surface in a regular pattern and in the correct orientation for antigen binding. QCM biosensor is 95.4 $\%$ sensitive and $98 \%$ specific compared to PCR. It is rapid and accurate clinical diagnostic tool for CPV infection (Kim et al, 2015).

\section{Prevention and control}

The prevention and control of CPV infection depends primarily on an effective immunization program; but disinfection, animal movement control and husbandry practices also must be considered especially in shelters. In most of the cases of CPV treatment supportive therapy is used which is based on suppression of symptoms and prevention of further complications. Since disease is very acute the supportive intravenous fluid therapy should be started as soon as possible. The dog may recover within 2-3 days. However, the treatment may not always be successful. Care should be taken that infected dogs should not be allow to come in contact with other healthy dog, because CPV may infect other healthy dog easily.

The disease can be prevented through proper vaccination. However, vaccination cannot be always successful because of prevalence of a large number of distinct antigenic variants of CPVs. For CPV control live attenuated as well as inactivated vaccines are used. There has been extensive research on these vaccines and their use in protecting dogs (Appel et al., 1979; Carmichael et al., 1983). First vaccination to puppies should be given at 8 weeks of age. Later on, vaccination is done at every 3-4 weeks for up to 4 months. The disease caused by CPV-2c can be prevented by vaccination of puppies at 6 weeks of age (Glover et al., 2012).
The hygiene in kennel should be appropriate for disease prevention, because CPV can be live on some surfaces years' together. The bleaching solution in water in a ratio of $1: 30$ can be used to kill the CPV. Owner should not allow the dog to go outside and mix with other stray or infected dogs. Proper care should be taken in waste matter disposal especially faeces of infected dogs.

\section{Conflict of interest}

Authors would hereby like to declare that there is no conflict of interests that could possibly arise.

\section{References}

Amo Alicia N del, Aprea, Adriana N, Petruccelli Miguel A (1999). Detection of viral particles in feces of young dogs and their relationship with clinical signs. Revista de Microbiologia, 30: 237-241. https://dx.doi.org/10.1590/S000137141999000300009 .

An DJ, Jeong W, Jeoung HY, Lee MH, Park JY, Lim JA, Park BK (2012) Peptide nucleic acid based (PNA) array for the antigenic discrimination of canine parvovirus. Research in Veterinary Science 93:515-519. doi:10.1016/j.rvsc.2011.06.003.

Anamul HA, Sharma K, Malik YS, Dhama K, Gupta PK (2015) Development of Real-time PCR assay for detection of rotavirus infection in diarrheic bovine calves. Advances in Animal and Veterinary Sciences 3: 321-324. doi.org/10.14737/journal.aavs/2015/3.6.321.324

Appel MJG, Scott FW, Carmichael LE (1979) Isolation and immunization studies of a canine parvo-like virus from dogs with haemorrhagic enteritis. Veterinary Record 105:156-159.

Banja BK, Sahoo N, Das PK, Swain P, Panda HK (2002) Comparison of different laboratory tests for diagnosis of parvo and corona viral infections in dogs. Indian Veterinary Journal 79: 425-428. 
Bargujar J, Ahuja A, Bihani DK, Kataria N, Dhuria D (2011) Studies on prevalence, clinical manifestations and therapeutic management in dogs suffering from canine parvovirus infection. Journal of Canine Development and Research 7: 916.

Behera M, Panda SK, Sahoo PK, Acharya AP, Patra RC, Das S, Pati S (2015) Epidemiological study of canine parvovirus infection in and around Bhubaneswar, Odisha, India. Veterinary World 8: 33-37. doi: 10.14202/vetworld.2015.3337.

Bodeus M, Cambiaso C, Surleraux M, Burtonboy GA (1988) latex agglutination test for the detection of canine parvovirus and corresponding antibodies. Journal of Virological Methods 19:1-12.

Buonavoglia C, Martella V, Pratelli A, Tempesta M, Cavalli A, Buonavoglia D, Bozzo G, Ella G, Decaro N, Carmichael L (2001) Evidence for evolution of canine parvovirus type 2 in Italy. Journal of General Virology 82 : 3021-3025. doi: 10.1099/0022-1317-82-12-3021.

Burtonboy G, Coignoul F, Delferriere N, Pastoret PP (1979) Canine haemorrhagic enteritis: detection of viral particles by electron microscopy. Archives of Virology 61: 1-11. DOI: 10.1007/BF01320586.

Carmichael LE, Binn LN (1981) New enteric viruses in the dogs. Advances in Veterinary Sciences and Comparative Medicine 25: 37.

Carmichael LE, Joubert JC, Pollock RV (1980) Haemaglutination by canine parvovirus: serological studies and diagnostic applications. American journal of veterinary research 41: 784-791.

Carmichael LE, Joubert JC, Pollock RV (1983) A modified live canine parvovirus vaccine. II. Immune response. Cornell Veterinarian 73: 13-29.

Castro TX, Miranda SC, Labarthe NV, Silva LE, Cubel Garcia RCN (2007) Clinical and epidemiological aspects of canine parvovirus (CPV) enteritis in the State of Rio de Janerio 19952004. Arquivo Brasileiro de Medicina Veterinária e Zootecnia, $59 \quad: \quad 333-339 . \quad$ http://dx.doi.org/10.1590/S010209352007000200010.

Chinchkar SR, Subramanian BM, Rao NH, Rangarajan PN, Thiagarajan D, Srinivasan VA (2006) Analysis of VP2 gene sequences of canine parvovirus isolates in India. Archives of Virology 151: 1881-1887. DOI: 10.1007/s00705-006-0753-8.

Cho HS, Kang JI, Park NY (2006) Detection of canine parvovirus in fecal samples using loop-mediated isothermal amplification. Journal of Veterinary Diagnostic Investigation $18: 81-84$.
Costa AP, Leite JP, Labarthe NV, Garcia RC (2005) Genomic typing of canine parvovirus circulating in the State of Rio de Janeiro, Brazil from 1995 to 2001 using polymerase chain reaction assay. Veterinary Research Communication 29: 735743. DOI: $10.1007 / \mathrm{s} 11259-005-3865-9$.

David Mech L, Almberg ES, Smith D, Goyal S, Singer RS (2012) Use of real-time PCR to detect canine parvovirus in feces of free-ranging wolves. Journal of Wildlife Diseases 48 : 473-476. doi: http://dx.doi.org/10.7589/0090-3558-48.2.473.

Decaro N, Desario C, Addie DD, Martella V, Vieira MJ, Elia G, Zicola A, Davis C, Thompson G, Iry G, Truyen U, Buonavoglia C (2007) Molecular Epidemiology of Canine Parvovirus, Europe. Emerging Infectious Disease 13: 12221224. doi: 10.3201/eid1308.070505.

Decaro N, Elia G, Martella V, Desario C, Campolo M, Trani LD, Tarsitano E, Tempesta M, Buonavoglia C (2005) A realtime PCR assay for rapid detection and quantitation of canine parvovirus type 2 DNA in the feces of dogs. Veterinary Microbiology 105: 19-28. doi:10.1016/j.vetmic.2004.09.018.

Decaro N, Martella V, Desario C, Bellacicco AL, Camero M, Manna L, d'Aloja D, Buonavoglia C (2006) First detection of canine parvovirus type $2 \mathrm{c}$ in pups with haemorrhagic enteritis in Spain. Journal of Veterinary Medicine B Infectious Disease and Veterinary Public Health 53: 468-472. DOI: 10.1111/j.1439-0450.2006.00974.x.

Deepa PM and Saseendranath MR (2012) Seroprevalence and diagnosis of canine parvoviral infection. Journal of the American Veterinary Medical Association 240 : 1084-1087.

Deka D, Phukan A, Sarma DK, Sutopa D (2015) Isolation of canine parvovirus in CRFK cell line from faecal samples of diarrhoeic dogs. Indian Journal of Veterinary Pathology 39(2): 129-131 doi: 10.5958/0973-970X.2015.00030.9.

Demeter Z, Palade EA, Soos T, Farsang A, Jakab C, Rusvai M (2010) Misleading results of the MboII-based identification of type2a canine parvovirus strains from Hungary reacting as type2c strains. Virus Genes $41: 37-42$. doi: 10.1007/s11262-010-0478-3.

Desario C, Decaro, N, Campolo M, Cavalli A, Cirone F, Elia G, Martella V, Lorusso E, Camero M, Buonavoglia C (2005) Canine parvovirus infection: which diagnostic test for virus. Journal of Virological Methods 126: 179-185. doi:10.1016/j.jviromet.2005.02.006.

Drane DP, Hamilton RC, Cox JC (1994) Evaluation of a novel diagnostic test for canine parvovirus. Veterinary Microbiology 41: 293-302. doi:10.1016/0378-1135(94)90109-0. 
Driciru M, Siefert L, Prager KC, Dubovi E, Sande R, Princee F, Friday T, Munson L (2006) A serosurvey of viral infections in lions (Panthera leo), from Queen Elizabeth National Park, Uganda. Journal of Wildlife Diseases 42:667-671.

Esfandiari J, Klingeborn B (2000) A comparative study of a new rapid and one-step test for the detection of parvovirus in faeces from dogs, cats and mink. Journal of Veterinary Medicine and Infectious Diseases Veterinary Public Health 47: 145-153. DOI: 10.1046/j.1439-0450.2000.00328.x.

Feng Y, Yang T, Xu Q, Sun E, Li J, Lv S, Wang H, Zhang Q, Zhang J, Wu D (2015) Detection, discrimination and quantitation of 22 bluetongue virus serotypes using real-time RT-PCR with TaqMan MGB probes. Archives of Virology 160 : 2249-2258. doi: 10.1007/s00705-015-2499-7.

Ganesan PI, Ramadass P, Gunaseelan (1990) Detection of canine coronavirus enteritis. Indian Veterinary Journal 67: 1088 .

Gauri DM, Jhala M K, Joshi CG( 2012) Genotyping of canine parvovirus by PCR and RFLP. International Journal of Advanced Biological Research 2 : 246-248.

Geetha M (2015) Epidemiology, pathogenesis, clinical findings and diagnosis of canine parvo viral infection. International Journal of Scientific Engineering and Applied Science 1: 21-27.

Glover S, Anderson C, Piontkowski M, Terry N (2012) Canine Parvovirus (CPV) type $2 \mathrm{~b}$ vaccine protect puppies with maternal antibodies to $\mathrm{CPV}$ when challenged with virulent CPV 2-C virus. International Journal of Applied Research in Veterinary Medicine 10: 217-224.

Gombac M, Svara T, Tadic M, Pogacnek M (2008) Retrospective study of canine parvovirus in Slovenia, Case report. Slovenia Veterinary Research 45: 73-78.

Gray LK, Crawford PC, Levy JK, Dubovi EJ (2012) Comparison of two assays for detection of antibodies against canine parvovirus and canine distemper virus in dogs admitted to a Florida animal shelter. Journal of the American Veterinary Medical Association 240 : 1084-1087. doi: 10.2460/javma.240.9.1084.

Gupta PK, Rai A, Rai N, Raut AA and Chauhan S (2005) Cloning of canine parvovirus VP2 gene and its use as DNA vaccine in dogs. Current Science 88 : 778-782.

Hoelzer K, Shackelton LA, Parrish CR, Holmes EC (2008) Phylogenetic analysis reveals the emergence, evolution and dispersal of carnivore parvoviruses. Journal of General Virology 89:2280-2289. doi: 10.1099/vir.0.2008/002055-0.

Kaur G, Chandra M, Dwivedi PN, Narang D (2016) Multiplex real-time PCR for identification of canine parvovirus antigenic types. Journal of Virological Methods 233: 1-5. doi: 10.1016/j.jviromet.2016.02.013.

Kaur G, Mudit C, Dwivedi PN, Deepti N (2015) Current approaches in the diagnosis of Canine Parvovirus: An Overview. Journal of Microbiology, Immunology and Biotechnology 2: 01-04.

Kim YK, Lim SI, Choi S, Cho IS, Park EH, An DJ (2015) A novel assay for detecting canine parvovirus using a quartz crystal microbalance biosensor. Journal of Virological Methods 219: 23-27. doi: 10.1016/j.jviromet.2015.03.015.

Klingeborn B, Moreno-López J (1980) Diagnostic Experience from an Epidemic of Canine Parvoviral Enteritis. Zentralblatt für Veterinärmedizin Reihe $\mathrm{B}$ 27: 483-488. doi: 10.1111/j.1439-0450.1980.tb01794.x

Kumar M, Nandi S, Verma R (2010) Development of SYBR Green based Real-Time PCR assay for quantitation of canine parvovirus in faecal samples. In: 7th Annual convention of ISACP on "Novel approaches in companion animal practice" held at Veterinary College, KVAFSU, Hebbal, Bangalore 2123: 146 .

Lin CN, Chien CH, Chiou MT, Wang JW, Lin YL, Xu YM (2014) Development of sybr green-based real-time PCR for the detection of canine, feline and porcine parvoviruses. Taiwan Veterinary Journal 40: 1-9. DOI: http://dx.doi.org/10.1142/S1682648514500012.

Litster AL, Pressler B, Volpe A, Dubovi E (2012) Accuracy of a point-of-care ELISA test kit for predicting the presence of protective canine parvovirus and canine distemper virus antibody concentrations in dogs. The Veterinary Journal 193: 363-366. doi: 10.1016/j.tvj1.2012.01.027.

MaCartney L, MaCartney CM (1986) Canine parvovirus: development of immunofluorescence and immunoperoxidase techniques. Research in Veterinary Science 40 : 201-208.

Marulappa SY, Kapil S (2009) Simple Tests for Rapid Detection of Canine Parvovirus Antigen and Canine Parvovirus-Specific Antibodies. Clinical and Vaccine Immunology 16:127-131. doi: 10.1128/CVI.00304-08.

Minakshi P, Koushlesh R, Basanti B, Supriya A, Mukhtar S, Alisha A, Pawan K, Joshi V. G, Savi J, Shweta B, Anjali S, Gaya P (2014) New Approaches for Diagnosis of Viral Diseases in Animals. Advances in Animal and Veterinary Sciences 20 : 55-63. http://dx.doi.org/10.14737/journal.aavs/2014/2.4s.55.63.

Mochizuki M, San Gabriel MC, Nakatani H, Yoshida M, Harasawa R (1993) Comparison of polymerase chain reaction with virus isolation and haemagglutination assays for the detection of canine parvoviruses in faecal specimens. Research 
in Veterinary Science 55: 60-63. doi:10.1016/00345288(93)90035-E.

MohanRaj J, Mukhopadhyay HK, Thanislass J, Antony PX, Pillai RM (2010) Isolation, molecular characterization and phylogenetic analysis of canine parvovirus. Infection Genetics and Evolution 10: 1237-1241. doi: 10.1016/j.meegid.2010.08.005.

Mukhopadhyay HK, Amsaveni S, Matta SL, Antony PX, Thanislass J, Pillai RM (2012) Development and evaluation of loop-mediated isothermal amplification assay for rapid and sensitive detection of canine parvovirus DNA directly in faecal specimens. Letters in Applied Microbiology 55: 202-209. doi: 10.1111/j.1472-765X.2012.03284.x.

Naidu H, Subramanian BM, Chinchkar SR, Sriraman R, Rana SK, Srinivasan VA (2012) Typing of canine parvovirus isolates using mini-sequencing based single nucleotide polymorphism analysis. Journal of Virological Methods 181: 197-201. doi: 10.1016/j.jviromet.2012.02.004.

Nandi S, Chidri S, Kumar M, Chauhan RS (2010) Occurrence of canine parvovirus type $2 \mathrm{c}$ in the dogs with hemorrhagic enteritis in India. Research in Veterinary Science 88: 169-171. doi: 10.1016/j.rvsc.2009.05.018.

Nho WG, Sur JH, Doster AR, Kim SB (1997) Detection of canine parvovirus in naturally infected dogs with enteritis and myocarditis by in situ hybridization. Journal of Veterinary Diagnostic Investigation 9: 255-260. doi: 10.1177/104063879700900306.

Parrish CR, Aquadro CF, Carmichael LE (1988) Canine host range and a specific epitope map along with variant sequences in the capsid protein gene of canine parvovirus and related feline, mink, and raccoon parvoviruses. Virology 166: 293307.

Parthiban M, Divya KC, Kumanan K, Bargavi DS (2012) A rapid and highly reliable field-based LAMP assay of canine parvovirus. Acta virologica 56: 71-74.

Pereira CA, Monezi TA, Mehnert DU, D’Angelo M, Durigon EL (2000) Molecular characterization of canine parvovirus in Brazil by Polymerase chain reaction assay. Veterinary Microbiology 75: 127-133. doi:10.1016/S03781135(00)00214-5.

Ramadass P, Latha D (2005) Multiplex PCR assay for diagnosis of canine parvovirus infection and leptospirosis. Indian Veterinary Journal $82:$ 365-368.

Ramsauer S, Bay G, Meli M, Hofmann-Lehmann R, Lutz H (2007) Seroprevalence of selected infectious agents in a freeranging, low-density lion population in the Central Kalahari Game Reserves in Botswana. Clinical and Vaccine Immunology 14: 808-810. doi: 10.1128/CVI.00307-06.
Rimmelzwaan GF, Groen J, Egberink H, Borst GHA, UytdeHaag FGCM, Osterhaus ADME (1991) The use of enzyme-linked immunosorbent assay systems for serology and antigen detection in parvovirus, corona virus and rota virus infections in dogs in Netherlands. Veterinary Microbiology 26: $25-40$.

Sakulwira K, Oraveerkul K, Poovorawan Y (2001). Detection and genotyping of canine parvovirus in enteric dogs by PCR and RFLP. Science Asia, 27: 143- 147.

Savi J, Minakshi P, Prasad G (2009). Genotyping of field strains of canine parvovirus in Haryana using PCR and RFLP. Indian Journal of Animal Sciences 79: 71-73.

Savi J, Minakshi P, Prasad G (2010) Rapid, sensitive and cost effective method for isolation of viral DNA from feacal samples of dogs. Veterinary World 3:105-106.

Shankar R, Chinchkar, Bhaskaran MS, Hariprasad N, Dorairajan T, Villuppanoor A, Srinivasan (2014) Canine Parvovirus Isolates of India and the Relevance of Canine Parvovirus type-2 Vaccines. Journal of Advanced Veterinary Research 4 : 34-41.

Sharma P, Rastogi A, Kartikaye K, Partap SN (2012) Sensitivity assay of polymerase chain reaction for detection of Canine Parvo Virus infection in dogs. Open Journal of Clinical Diagnostics 2: 45-47.

Shima FK, Apaa TT, Mosugu JIT (2015) Epidemiology of Canine Parvovirus Enteritis among Hospitalized Dogs in Effurun/Warri Metropolitan Region of Delta State, Nigeria. Open Access Library Journal 2 e1208. doi:http://dx.doi.org/10.4236/oalib.1101208.

Silva MMO, Castro1 TX, Costa1 EM, Trancoso1 TAL, Mendes-de-Almeida NVF, Labarthe RCN, Cubel G (2013) Comparison of three laboratorial tests for diagnosis of canine parvovirus infection. Arquivo Brasileiro de Medicina Veterinária e Zootecnia 65: 149-152. doi.org/10.1590/S010209352013000100023.

Singh D, Verma AK, Kumar A (2014) Phylogenetic analysis of canine parvovirus isolates from Mathura, India. Veterinarski Arhiv 84: 505-512.

Singh D, Verma AK, Kumar A, Srivastava M, Singh SK, Tripathi AK, Srivastava AK and Ahmad I (2013) Detection of canine parvovirus by PCR assay and its prevalence in dogs in and around Mathura Utter Prdesh India. American Journal of Biochemistry and Molecular Biology 3: 264-270. DOI: 10.3923/ajbmb.2013.264.270.

Sun YL, Yen CH, Tu CF (2014) Visual detection of canine parvovirus based on loop-mediated isothermal amplification combined with enzyme-linked immunosorbent assay and with lateral flow dipstick. The Journal of Veterinary Medical 


\section{0}

Science 76: 509-516. DOI: http://doi.org/10.1292/jvms.130448 .

Truyen U (2006) Evolution of canine parvovirus-A need for new vaccines? Veterinary Microbiology 117: 9-13. doi:10.1016/j.vetmic.2006.04.003.

Truyen U, Gruenberg A, Chang SF, Obermaier B, Veijalainen P, Parrish CR (1995) Evolution of the feline subgroup of parvoviruses and the control of canine host range in vivo. Journal of Virology 69: 4702-4710.

Uwatoko K, Sunairi M, Nakajima N, Yamaura K (1995) Rapid method utilizing polymerase chain reaction for detection of canine parvovirus in faeces of diarrheic dogs. Veterinary Microbiology 43: 315-323. doi:10.1016/0378-1135(94)001023.

Wang X, Rena L, Qin T, Wang J, Zhang Y, Manlin L, Liub R, Wang J (2011) Magnetic protein microbead-aided indirect
Minakshi et al

fluoroimmunoassay for the determination of canine virus specific antibodies. Biosensors and Bioelectronics 26: 33533360. doi: 10.1016/j.bios.2011.01.018.

Wei X, Jian L, Lu Q, Li H, Gao, Jing J, Chun Y, Zhong RH, Yong QH (2009) Rapid detection of Canine parvovirus by realtime PCR and PCR methods. Chinese Journal of Veterinary Science 29: 36-40.

Zhang Q, Xu XM, Zhai GQ, Wang Z, Hou HS, Zhu HF (2010) Molecular characterisation of canine parvovirus strains circulating in China. African Journal of Biotechnology 9 : 4556-4560.

Zhao Y, Lin Y, Zeng X, Lu C, Hou J (2013) Genotyping and pathobiologic characterization of canine parvovirus circulating in Nanjing China. Virology Journal 10: 272-372. doi: 10.1186/1743-422X-10-272. 